\title{
A handout about tetanus immunisation: influence on immunisation rate in general practice
}

\author{
Christopher J Cates
}

\begin{abstract}
Objective-To assess the influence of giving patients a handout about tetanus immunisation on the rate of immunisation against tetanus among adults in a general practice.

Design-Monthly tetanus immunisation rates were audited before and after the handout was introduced.

Setting - A practice with six doctors and a list of 11000 patients in an urban area of Hertfordshire.

Interventions - In the first month reception staff were instructed to give a handout about tetanus immunisation to all adults presenting at the reception desk. In the next seven months the doctors used the handouts opportunistically during consultations.

Results-No significant change in immunisation rate was detected in the first month in which the handouts were used. During the next seven months the median monthly rate rose threefold.

Conclusion-Handouts given to patients can increase the uptake of preventive services in general practice.
\end{abstract}

\section{Introduction}

In September 1988 Howie argued that adults should be offered a routine tetanus booster immunisation every 10 years. ${ }^{1}$ In October this practice, a group of six general practitioners, decided to encourage patients to make an appointment with the practice nurse for immunisation if they had no record or recollection of having received a tetanus vaccination in the previous 10 years. If they had never received tetanus immunisation a full course of treatment would be recommended. If they had received tetanus immunisation from any source in the past 10 years this was to be recorded on the practice computer.

It became clear in January 1989 that these good intentions had not been transformed into changed behaviour - a demonstration of the gap between knowledge, attitudes, and practice. ${ }^{2}$ I decided, therefore, to see whether using a handout would improve uptake.

\section{Methods}

A handout (box) was devised and placed on the reception desk in the practice. The receptionists were told to offer one to each adult presenting during February 1989. The receptionists were told the handout's purpose and challenged to achieve better results than the doctors who were to use the handouts in March. In March the handouts were duly removed from reception and placed on each doctor's desk to be offered to patients during consultations.

The monthly totals of tetanus immunisations given to adults over the previous four years were obtained from the practice's records and compared with the totals for the months after the introduction of the handout on 1 February 1989. The proportion of adults aged over 30 who were recorded as having received a tetanus immunisation in the previous 10 years was also checked each month.
Are you and your family protected against tetanus?

Tetanus still kills people in this country today. There is no shortage of vaccine to protect us all, and children receive a course of vaccine routinely, but many adults are not properly protected. If you have not had a tetanus booster in the past 10 years please make an appointment with the nurse to have this done soon.

\section{Results}

No change in immunisation rate (figures for booster and primary immunisations combined) was seen after the initial decision in October 1988 to promote immunisation, and the rate in February 1989 (35 injections) was only marginally higher than the figures for the previous years (figure): handouts given to patients by the receptionists had little impact. In March, when handouts were first used by the doctors, the immunisation rate rose to 59 . Of the 59 patients, 30 had visited the doctor in March and five in February. The increase did not, therefore, originate from handouts distributed in February.

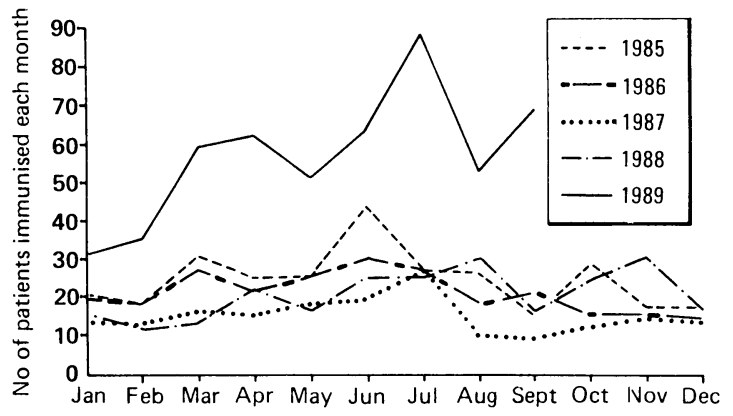

Numbers of adult patients in practice who received tetanus immunisation, January 1988 to September 1989

Because of the results achieved in March the doctors used the leaflets for the next six months; the rise was sustained over this period (figure). The median number of injections each month was 18 before the handouts were used by the doctors and 62 subsequently $(\mathrm{p}<0.001$, Mann-Whitney U test; difference 44 per month (95\% confidence interval 35 to 50$)$ ).

The proportion of immunisations that were part of a primary course was $20 \%$ before the doctors used the handout and 25\% after March 1989. The increased number of injections cannot, therefore, simply be accounted for by a rise in the proportion given as part of a primary course.

The number of patients over the age of 30 recorded on the computer as having received a tetanus injection in the past 10 years rose steadily during the period when the handouts were in use, from $122(1.8 \%)$ in January, before they were used, to $650(9 \cdot 7 \%)$ in September. 


\section{Discussion}

Retrospective audit carried out in January 1989 showed that tetanus immunisation was not a high priority in the practice's health promotion strategy, and a decision to change this had not altered our behaviour. Major factors preventing change in doctor's behaviour are pressure of time in consultations and previous consulting habits. These we overcame to a large extent by devising the short handouts, which took very little time to use and served as a physical reminder to ask about tetanus immunisation.

The short time allowed for the receptionists to use the handout precludes firm conclusions about this method of encouraging preventive medicine, although pressure of time played a part here too: after the enthusiasm of the first week the rate of distribution of the leaflets fell dramatically-receptionists can also forget or be too busy.

Further studies are needed to see whether results similar to this threefold increase in tetanus immunisation rate can be achieved with handouts about other aspects of preventive medicine.

I thank my partners for their cooperation; the nurses who gave the injections; and $\mathrm{Mr} \mathrm{R}$ Chapman for help with the statistical analysis.

1 Howie JGR. Anyone for tetanus? Br Med f 1988;297:570-1

O'Dowd TC, Sprackling PD. Continuing medical education in general practice. BrMed f 1989;298:1472.

(Accepted 19 January 1990)

BOOKS RECEIVED

\section{Gastroenterology}

Developments in Gastroenterology. Vol 9. "The Role of Laser in Gastroenterology: Analysis of Eight Years' Experience." E M H Mathus-Vliegen. (Pp xiv +207 ; figs and colour plates; £59.) Dordrecht: Kluwer Academic, 1989. Distributed by MTP Press. ISBN 0-7923-0425-X

Gastrointestinal Motility: Which Test? Ed N W Read. (Pp x + 294; figs; £35.) Petersfield: Wrightson Biomedical, 1989. Distributed by Blackwell Scien1989. Distributed by Black
tific. ISBN 1-871816-00-9.

Inflammatory Disease and Therapy. Vo 2. "Therapy of Inflammatory Bowe Disease: New Medical and Surgica Approaches." Ed M A Peppercorn. Series editor D E Furst. (Pp xii + 291; figs; $\$ 150.00$.) New York: Dekker, 1990. ISBN 0-8247-8169-4.

\section{General practice}

Brain Scan MCQs. "MCRGP." P G Elliott. (Pp vii+192; $\{9.95$ paperback.) London: Springer, 1989. ISBN 3-540-19563-7.

Depression: Recognition and Treatment in General Practice. G Wilkinson. (Pp xii +95 ; 18.50 paperback.) Oxford: Radcliffe Medical Press, 1989. ISBN 1-870905-16-4

Practical Guides for General Practice. 11. "Child Health: the Screening Tests." A Macfarlane, S Sefi, M Cordeiro. (Pp v +57 ; figs; $\{4.50$ paperback.) Oxford: Oxford Univer
Press, 1989. ISBN 0-19-261768-0.

Practice Receptionist Programme 2. Course Training Package consisting of textbook edited by $M$ Whalen, editorial consultant $M$ Drury + binder of course notes + new training video+the Joint Committee's cerificate for those Joint Commitee's certicate for those who complete the course satisfactorily. Course fee $\{79$ (inc. VAT), 70\% re mbursable under Paragraph 52.9 he Statement of Fees and Allowances. Fee covers catering, tuition, and train-
ing package as detailed above. Further information from PRP Central Administrative Office, Radcliffe Medical Press Limited, 27 Park End Street, Oxford OXI IHU.

\section{Health care issues}

The Health Advisory Service: an Evaluation. M Henkel, M Kogan, T Packwood, et al. (Pp vii +104; $\$ 9.95$ paperback.) London: King Edward's Hos pital Fund for London, 1989. ISBN 1-870551-97-4.

The Rock Carling Fellowship 1988. "On Caring for the National Health." Sir Kenneth Stowe. (Pp ix +90 ; 9 including postage and packing.) London: Nuffield Provincial Hos-
pitals Trust, 1989. ISBN 0-90057471-2.

History of medicine

Eponymists in Medicine. "Robert Graves: the Golden Years of Irish
Medicine." S Taylor. Editor in chief H L'Etang. (Pp vii +160 ; figs; $£ 7.95$ Medicine Services, 1989. ISBN 0-905958-90-X.

Science and Medicine in the Old South. Ed R L Numbers, T L Savitt. (Pp xii + 370 ; 33.75 .) Baton Rouge: Louisian State University Press, 1989. ISBN 0 8071-1464-2.

\section{Immunology}

The Body at War: the Story of Our Immune System. J Dwyer. (Pp xi+253; figs; colour plates; $£ 6.99$ paperback. London: Unwin, 1989. ISBN 0-04820039-5.

Immunology and Medicine Series. Vol 12. "Recent Developments in Prophylactic Immunization." Ed A I Zuckerman. Series editor $\mathrm{K}$ Whaley. (Pp x+ 340; figs; £45.) Dordrecht: Kluwer Academic, 1989. Distributed by MTP Press. ISBN 0-7923-8910-7.

Infection

World Health Organisation Technical Report Series. No 784. "The Use of Synthetic Antigens for Diagnosis of Infectious Diseases." Report of WHO scientific group. (Pp 74; Sw fr 9 paperback.) Geneva: World Health Organisation, 1989. ISBN 92-4 120784-1.

\section{Medicolegal}

AIDS: a Guide to the Law. Ed D Harris, R Haigh, for the Terrence Higgins Trust. (Pp xiv $+192 ; £ 9.95$ paperback.) London: Routledge, 1990. ISBN 0-415-04668-8.

Developments in Critical Care Medicine and Anesthesiology. Vol 21. "Legal Aspects of Anaesthesia." Ed J F Crul. (Pp $x+134$; figs; £30.) Dordrecht: Kluwer Academic, 1989. Distributed by MTP Press. ISBN 0-7923-0393-8. Medical Law: Text and Materials. Kennedy, A Grubb. (Pp xliii +1224 $£ 30$ paperback.) London: Butterworth Scientific, 1989. ISBN 0-406-50041 $\mathrm{X}$.

Medical Malpractice Solutions: System and Proposals for Injury Compensation. Ed M M Halley, R J Fowks, F C Bigler, D L Ryan. (Pp xxv +305 $\$ 49.75$. Illinois: Thomas, 1989. ISBN 0-398-05600-5.

Microbiology

Medical Microbiology and Immunology 1989: Examination and Board Review. W Levinson, E Jawetz. (Pp x+436; figs; $\{22.25$ paperback.) London: Prentice-Hall International, 1989. ISBN 0-8385-6239-6.

\section{Nephrology}

Developments in Nephrology. Vol 23. "Continuous Ambulatory Peritoneal Dialysis in the USA: Final report of
the National CAPD Registry 1981-
1988." Ed A S Lindblad, J W Novak, K D Nolph. (Pp xiv+303; figs; $£ 62$.) Dordrecht: Kluwer Academic, 1989 Distributed by MTP Press. ISBN 0-7923-0179-X.

\section{Neurology}

Atlas of Electroencephalography. A Guberman, M Couture. (Pp xv +220 figs; £110.) Boston: Little, Brown 1989. Distributed by Churchill Livingstone. ISBN 0-316-33074-4.

Contemporary Neuroscience. "PsychoConsive Drugs: Tolerance and Sensization." Ed A J Goudie, $M$ W EmmetOglesby. (Pp xv+600; figs; $\$ 89.50$. New Jersey: Humana Press, 1989. ISBN 0-89603-148-9.

The EEG Handbook. F M Dyro. Pp ix+99; figs; $£ 15.95$ paperback. Boston: Little, Brown, 1989. Distr buted by Churchill Livingstone. ISBN 0-316-20019-0.

Nutrition

Handbook of Child Nutrition. L S Taitz, B L Wardley. (Pp ix + 182; figs; $\{22$.) Oxford: Oxford University Press, 1989. ISBN 0-19-261759-1.

International Life Sciences Institut Human Nutrition Reviews. "Dietary Starches and Sugars in Man: a Comparison." Ed J Dobbing. (Pp xiv +256 figs; £59.) London: Springer, 1989. ISBN 3-540-19560-2.

World Review of Nutrition and Dietetics. Vol 59. "Impact of Nutrition on Health and Disease." Volume and Series editor G H Bourne. (Pp xi+220; figs editor G.) Basel: Karger, 1989. Distributed by John Wiley and Sons. ISBN 3-8055-4919-9.

\section{Obstetrics and gynaecology}

Fetal Growth. Ed F Sharp, R B Fraser, R D B Milner. (Pp viii +428; figs; 559.50.) London: Springer, 1989 ISBN 3-540-19562-9.

A Guide to Effective Care in Pregnancy and Childbirth. M Enkin, $M \mathrm{~J} \mathrm{~N} \mathrm{C}$ Keirse, I Chalmers. (Pp xiii +376 ; £9.95 paperback.) Oxford: Oxford

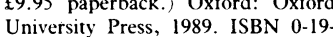
261916-0.

Gynaecological Endocrinology: a (juide to Understanding and Management. $M$ Dalton. (Pp viii +136; figs; 225 . London: Macmillan, 1989. ISBN $0-333-47430-9$

\section{Occupational medicin}

The Corporate Healthcare Revolution Strategies for Preventive Medicine a Work. D Ashton. (Pp 396; figs; £30.) London: Kogan Page, 1989. ISBN 1-85091-694-2.

\section{Oncology}

Cancer Growth and Progression. Vol 9 "Cancer Management in Man: Detection, Diagnosis, Surgery, Radiology,

Chronobiology, Endocrine Therapy." Ed A L Goldson. Series editor H E Kaiser. (Pp x+296; figs; £59.95.) Dordrecht: Kluwer Academic, 1989. Distributed by MTP Press. ISBN 089838-998-4.

Cancer Growth and Progression. Vol 10. "Cancer Management in Man: Biological Response Modifiers, Chemotherapy, Antibiotics, Hyperthermia, Supporting Measures." Ed P V Woolley. Series editor H E Kaiser. (Pp x+248; figs; 559.95.) Dordrecht:
Kluwer Academic, 1989. Distributed by MTP Press. ISBN 0-89838-999-2. Cancer Treatment and Research. "Drug Resistance in Cancer Therapy." Ed Resistance in Cancer Therapy." Ed
RFOzols. Series editor W L McGuire. (Pp xiii+210; figs; $£ 60.50$.) Boston: (Pp xiii+210; figs; 160.50 .) Boston: by MTP Press. ISBN 0-7923-0244-3. Cancer Treatment and Research. "Endometrial Cancer,"EdE A Surwit, D S Alberts. Series editor W L McGuire. (Pp xiv +131; figs; 555.75 .) Guire. (Pp xiv 131 ; fgs, L55.75.) Boston: Kluwer Academic, 1989 . Dis0286-9.

Cancer Treatment and Research. "Oncogenes." Ed C Benz, E Liu. Series editor W L McGuire. (Pp xii +339; figs; £79.95.) Boston: Kluwer Academic, 1989. Distributed

Digestive Disease Pathology. Vol 1. Ed $S$ Watanabe, $M$ Wolff, $S \mathrm{C}$ Sommers. (Pp viii $+229 ; £ 36$.) New York: Mac millan, 1989. ISBN 0-02-424570-4

IARC Monographs on the Evaluation of Carcinogenic Risks to Humans. Vol 45. "Occupational Exposures in Petroleum Refining; Crude Oil and Major Petroleum Fuels. "International Agency for Research on Cancer. (Pp 322; Sw frs 65 papertack 